graphic brush cytology has proved negative by using a fine spring-loaded Tru-cut needle Biopty gun (Biopty TM, Radiplast, Uppsala), percutaneously under ultrasound guidance.

The use of self expanding metal stents was alluded to in the leading article, and a primary indication would be those patients with nonresectable hilar cholangiocarcinoma in whom good survival might be expected. There is no evidence that the optimum route of insertion for these metal stents is via the transhepatic route, and there are many advantages in placing metal stents endoscopically.

\section{Low strictures}

Messrs Russell and Rees failed to reference Roux en Y choledochojejunostomy as the preferred procedure for biliary drainage, for there is none except surgical history. In fact, conventional choledochoduodenostomy is an adequate bypass and this has the added advantage of easing endoscopic procedures later if nodes or tumour growth around the porta hepatis occlude the bile duct.

We agree that there are a few figures suggesting an improved survival after radical resection, but numbers are small and very few centres achieve a $5 \%$ mortality, and cures are rare. The improved survival may merely indicate the improved selection.

We agree with Professor Cotton that difficulties do arise in the management of a few patients for whom resective surgery may be the correct approach. The patients are best cared for in a unit which has a specialist team of interventional endoscopists, radiologists, and a pancreatobility surgeon.

In the article routine stenting was not advocated; in fact, it was clearly pointed out that clinicians now have to take a mature approach in their decision making, and have to balance the patient's condition and likelihood of survival before deciding on a surgical or an endoscopic approach to palliation. Clearly, there are going to be some patients who look fit and well, and in whom some form of surgical palliation may be appropriate to reduce the need for admissions, which would be necessary in the patient stented endoscopically. At the other end of the spectrum there are those patients over the age of 70 years in whom a simple stenting procedure seems a very suitable alternative to any form of surgical palliation, particularly, when we know that most patients die jaundice free with their original stent in situ.

A R W HATFIELD R C G RUSSELL Department of Gastroenterology, Middlesex Hospital,
London WIN $8 A A$

1 Polydorou AA, Cairns SR, Dowsett JF, et al. Palliation of proximal malignant biliary obstruction by endoscopic endoprosthesis insertion. Gut 1991, 32: 685-9.

2 Cotton PB. Endoscopic management of bile duct stones: (apples and oranges). Gut 1984; 25 : 587-
97.

Ultrastructural demonstration of histamine in human enterochromaffin like cell granules

SIR, - We read with great interest the paper by Lönroth et al.' By using immunohistochemical methods in light microscopy in normal volunteers, the authors showed that in addition to mast cells some gastric endocrine cells contained histamine. These cells were located exclusively in the fundus, constituted $44 \%$ of the total number of endocrine cells in the oxyntic mucosa, and stored neither 5 hydroxy-

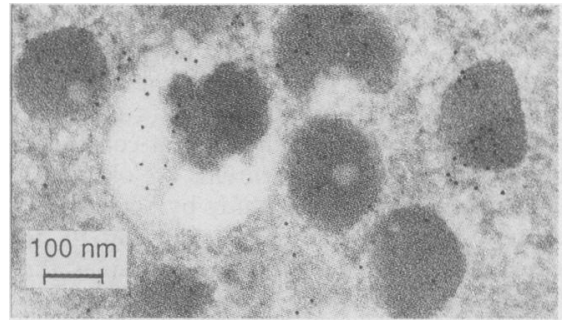

Ultrastructural histamine demonstration in enterochromaffin like cell secretory granules on human fundus biopsy section. The $5 \mathrm{~nm}$ gold particles are located in the electron dense granules and inside a typical vacuolated granule (original magnification $\times 60110^{3}$ ).

tryptamine nor somatostatin. These endocrine cells were supposed to be enterochromaffin like cells.

To study this hypothesis, we tried to demonstrate histamine (HA) in the enterochromaffin like cells by an immunocytochemical method in electron microscopy. Ultrastructural analysis of fundic sections, indeed, allow enterochromaffin like cells to be distinguished, with their typical secretory granules, from the other gastric endocrine cells. ${ }^{2}$ This study was done in a patient with pernicious anaemia, hypergastrinaemia ( $>1000 \mathrm{pg} / \mathrm{ml}$ ), and micronodular hyperplasia of argyrophilic cells (Grimelius argyrophil technique). Fundic mucosal biopsy specimens were obtained during gastroscopy, fixed in $4 \%$ glutaraldehyde in phosphate buffer at $20^{\circ} \mathrm{C}$, dehydrated in ethanol, and embedded in Epon 812. Ultrathin sections were cut and mounted on gold grids. They were incubated for four hours in 1/200 diluted polyclonal guinea pig anti-HA antibodies (Peninsula ref 61069) at room temperature and rinsed in phosphate buffer and in distilled water. The grids were then incubated for one hour in a $5 \mathrm{~nm}$ gold particle conjugated antiguinea pig immunoglobulin (Biocell EMGAG5), 1/20 diluted in phosphate buffer solution. Finally, the grids were rinsed in water, dried, and contrasted with uranyl acetate in ethanol.

The efficiency and the specificity of the immunocytochemical reaction were first checked on rat peritoneal mast cell (PMC) sections. Normal rat PMC granules were shown to contain HA while, after in vitro incubation in a poly-L-lysine (secretagogue) solution, ${ }^{3}$ the PMC granules no longer contained HA.

In the human biopsy sections few mast cells were present around the gland. They were shown to contain HA in their uniformly electron dense granules. The enterochromaffin like cells were identified ultrastructurally. Most of these cells contained granules positively marked by the anti-HA immunocytochemical reaction (Figure). This reaction was reproduced several times on many sections of the same biopsy specimen with concordant results. The control sections were incubated either with anti-HA neutralised by HA followed by the immunogold reaction, or with immunogold reagent alone. They were both negative except a light aspecific background.

The results of this study are in agreement with Lönroth's conclusions: the histaminecontaining endocrine cells of the human fundus are enterochromaffin like cells. The role of these cells in the physiology of histamine mediated acid secretion should be explored. Further studies should determine if the cell granules release histamine under the influence of gastrin.

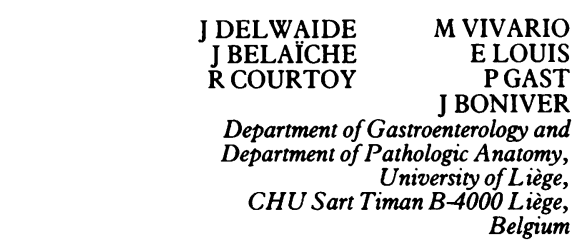

Correspondence to: Dr Jean Delwaide

1 Lönroth $\mathrm{H}$, Håkanson $\mathrm{R}$, Lundell $\mathrm{L}$, Sundler $\mathrm{F}$ Histamine containing endocrine cells in the Histamine containing endocrine cells
human stomach. Gut 1990; 31: 383-8.

2 Hakanson R, Böttcher G, Sundler F, Vallgreen S. Activation and hyperplasia of gastrin and enterochromaffin-like cells in the stomach. Digestion 1986; 35 (suppl 1): 23-41.

3 Courtoy R, Boniver J, Simar LJ. Cytochemistry of mouse mast cell reaction to polylysine. Histochemistry 1980; 66: 49-58.

\section{Reply}

SIR, - Dr Delwaide and colleagues have with this report further confirmed that the enterochromaffin like cells of the human fundus indeed contain histamine. In the human gastric mucosa these cells are confined to the oxyntic gland area, which also presents a higher histidine decarboxylase activity than the nonacid producing pyloric gland region. ${ }^{1}$ Patients with hypergastrinaemia of different origin also have a higher histidine decarboxylase activity together with an increased density of enterochromaffin like cells in the oxyntic gland area. $^{2-4}$ In addition, pentagastrin infusion is followed by a release of histamine and by a substantial increase in histidine decarboxylase activity in the oxyntic gland mucosa of healthy volunteers. These penragastrin induced events do not occur in the pyloric gland region. 4

In conclusion, all this circumstantial evidence together with the results presented by Dr Delwaide and colleagues favour the view that the enterochromaffin like cells of the human stomach store histamine, release the amine on proper stimulation, and have the capacity to synthesise histamine.

\section{H LÖNROTH University of Götebor Department of Surgery II, S-41345 Göteborg, Sweden}

1 Lönroth H, Lundell L, Rosengren E. Histamine metabolism of the human stomach - a study on the regional distribution of the amine and enzyme activities. Scand 7 Clin Lab Invest 1989; 49: 23-31.

2 Cattan D, Roucayrol AM, Launay JM, Callebert J, Charasz N, Nurit Y, et al. Circulating gastrin, endocrine cells, histamine content and histidine decarboxylase activity in atrophic gastritis. Gastroenterology 1989; 907: 586-96.

3 Bordi C, Cocconi G, Togni R, Vezzadini P, Missalo $G$. Gastric endocrine cell proliferation; association with Zollinger Ellison syndrome. Arch Pathol 1974; 98: 274-8.

4 Lönroth H, Lundell L, Rosengren E, Olbe L. Histamine metabolism of the human gastric mucosa - effect of pentagastrin stimulation. Gastroenterology 1990; 98: 921-8.

\section{BOOK REVIEWS}

Textbook of secretory diarrhea. By Emanuel Lebenthal and Michael E Duffey. (Pp 456; illustrated; \$132.) New York: Raven Press, 1990.

Although secretory diarrhoea is not everyone's cup of tea, I approached this book with some 